\title{
THE ASSOCIATION BETWEEN RISK FACTORS AND ULTRASOUND-BASED GRADES OF NON-ALCOHOLIC FATTY LIVER DISEASE IN TYPE-2 DIABETES PATIENTS
}

\author{
FX Himawan Haryanto Jong ${ }^{1)}$, Prettysun Ang Mellow ${ }^{2)}$
}

\begin{abstract}
Background: Non-alcoholic fatty liver disease (NAFLD) has become more common as the cause of cirrhosis and liver cancer. The liver disease is highly prevalent in people with type-2 diabetes. Indonesia is not spared from the global epidemic of type-2 diabetes. The ultrasound examination is clinically easy-to-use, economical and non-invasive as a tool to detect NAFLD, compared to the gold standard, liver biopsy. To date, there has been no study in Indonesia to link risk factors and ultrasound-based severity grading of NAFLD. Aim: To understand the association between risk factors and ultrasound-based grades of NAFLD in patients with type2 diabetes. Method: The present study was an observational study with a cross-sectional design (May-October 2018) that involved 82 type-2 diabetes outpatients of the internal medicine clinic in the Gotong Royong Hospital (Surabaya, Indonesia). The risk factors assessed were gender, age, diabetes duration, obesity (anthropometric measurement: body mass index/ BMI, waist circumference and waist-to-hip ratio), glycemic control (hemoglobin Alc/ HbAlc level) and dyslipidemia (lipid profile: total cholesterol, low-density lipoprotein/ LDL, high-density lipoprotein/HDL and triglyceride). The ultrasound-based grades of NAFLD consisted of grade 0 (no NAFLD), grade 1 (increased liver echogenicity with normal images of intrahepatic vessel lines and diaphragm), grade 2 (blurred image of intrahepatic vessel lines) and grade 3 (blurred images of intrahepatic vessel lines and diaphragm). Statistical p-value was significant at $\leq$ 0.05. Results: Seventy-eight subjects $(95,1 \%)$ had NAFLD. The ultrasound-based NAFLD grades were significantly different across age groups (Kruskal-Wallis) but the Spearman's rank correlation test result was not significant. Body mass index and total cholesterol were positively correlated ( $r=0.390$ and 0.237, respectively) with the NAFLD grades. Conclusion: Higher BMI and total cholesterol are associated with increased ultrasound-based NAFLD grades.
\end{abstract}

Keywords: Diabetes Tipe 2, Non-Alcoholic Fatty Liver Disease, Risk Factors, Ultrasonography 


\section{ABSTRAK}

Latar belakang: Penyakit perlemakan hati non-alkoholik menjadi lebih sering sebagai penyebab sirosis dan kanker hati. Penyakit hati ini memiliki prevalensi tinggi pada orang yang menderita diabetes tipe 2. Indonesia juga memiliki prevalensi penyakit diabetes tipe 2 yang tinggi seperti di dunia. Pemeriksaan ultrasonografi mudah secara klinis, murah dan tidak invasif untuk mendeteksi penyakit perlemakan hati non-alkoholik, dibandingkan biopsi hati sebagai standar emas. Sampai saat ini, belum ada studi di Indonesia yang menghubungkan faktor risiko dan derajat keparahan penyakit perlemakan hati non-alkoholik berdasarkan ultrasonografi. Tujuan: Untuk memahami hubungan antara faktor risiko dan derajat penyakit perlemakan hati non-alkoholik berdasarkan ultrasonografi pada pasien diabetes tipe 2. Metode: Studi ini adalah suatu studi observasional dengan desain potong lintang (Mei-Oktober 2018) yang melibatkan 82 pasien diabetes tipe 2 di poli penyakit dalam, Rumah Sakit Gotong Royong (Surabaya, Indonesia). Faktor risiko yang dinilai adalah jenis kelamin, usia, lama menderita diabetes, obesitas (indeks massa tubuh, lingkar pinggang dan rasio lingkar pinggang-pinggul), kontrol glikemik (kadar HbA1c) dan dilipidemia (profil lipid: kolesterol total, LDL, HDL dan trigliserida). Derajat penyakit perlemakan hati non-alkoholik berdasarkan ultrasonografi terdiri dari derajat 0 (tidak ada penyakit perlemakan hati non-alkoholik), derajat 1 (peningkatan ekogenisitas hati dengan gambaran normal batas pembuluh darah intrahepatik dan diafragma), derajat 2 (pengaburan gambaran batas pembuluh darah intrahepatik) dan derajat 3 (pengaburan gambaran pembuluh darah intrahepatik dan diafragma). Nilai statistik p signifikan pada $\leq 0.05$. Hasil: Tujuh puluh delapan $(95,1 \%)$ subyek memiliki penyakit perlemakan hati non-alkoholik. Derajat penyakit perlemakan hati non-alkoholik berdasarkan ultrasonografi berbeda secara signifikan antar kelompok usia (Kruskal-Wallis) tetapi hasil tes korelasi Spearman tidak signifikan. Indeks massa tubuh $(\mathrm{r}=0.390)$ dan kolesterol total $(\mathrm{r}=0.237)$ berkorelasi secara positif dengan derajat NAFLD berdasarkan ultrasonografi. Simpulan: BMI dan kolesterol total yang lebih tinggi berhubungan dengan peningkatan derajat penyakit perlemakan hati nonalkoholik berdasarkan ultrasonografi.

Kata kunci: diabetes tipe 2, penyakit perlemakan hati non-alkoholik, faktor risiko, ultrasonografi

\footnotetext{
1) Department of Anatomy and Histology, Faculty of Medicine, Widya Mandala Catholic University Surabaya, Indonesia. 2) Department of Internal Medicine, Faculty of Medicine, Widya Mandala Catholic University Surabaya, Indonesia \#Email address: himawan@ukwms.ac.id, phone number: +6281237707797
} 


\section{INTRODUCTION}

Non-alcoholic fatty liver disease is presently the world's most common chronic liver disease. Based on results from a recent meta-analysis study, the disease worldwide prevalence is $25 \%$ (1). Owing to the change from an agrarian to industrial society that promotes an unhealthy diet and lifestyle, the prevalence of the disease in Asia has stacked up against the global one (around 25\%) (2). Although studies about NAFLD conducted in Indonesian communities are still few, a systematic review which gathered data from hospital-based research has mentioned that the prevalence of the disease in the country is $30 \%$ (3).

Non-alcoholic fatty liver disease is a chronic liver disease which histological hallmarks are similar to the alcohol-induced liver disease but the patients have no history of excessive alcohol intake. It encompasses a spectrum of liver disease that ranges from simple steatosis to non-alcoholic steatohepatitis (NASH). The latter is likely to develop into liver cirrhosis and subsequently liver cancer. The multiple-hit pathogenesis is hitherto widely accepted as how NAFLD is initiated and progresses to become NASH, cirrhosis and liver cancer. In the pathogenesis theory, multiple factors are attributed to disease progression. Insulin resistance is followed by hepatic fat accumulation that causes inflammation of liver tissue. Gut microbiota imbalance and genetic predisposition are also factored in (4-6). A 2013 population-based study in the US revealed that NASH-related liver cancer was the second-highest cause of liver transplantation (7). Non-alcoholic fatty liver disease is also an independent risk factor for patients to develop cardiovascular diseases (8).

Diagnosis of NAFLD has been made in $70-75 \%$ of patients with diabetes mellitus. This is not surprising as insulin resistance is the key factor in the NAFLD pathogenesis $(9,10)$. A 10-year cohort study that involved more than 500.000 people in China has shown that subjects with diabetes have higher risks to develop NAFLD (hazard ratio 1,07$)$, cirrhosis $(1,07)$ and liver cancer $(1,04)$ than those without diabetes (11). About $9 \%$ of adults in the world suffered from diabetes mellitus in 2015 according to the data from The International Diabetes Federation and Asia as the most populous continent contributed the most to the number. It is noteworthy that Indonesia is the third most populous country in Asia. Type-2 diabetes which is lifestyle-related holds the majority (90\%) (12).

Age, gender and other features of metabolic syndrome (obesity, diabetes, and dyslipidemia) are risk factors of NAFLD that have been studied in populations (13). A research paper published in 2017 showed that the prevalence of NAFLD among patients with type 2 diabetes that visited 
Cipto Mangunkusumo Hospital in Jakarta was $45.2 \%$ and $25.0 \%$ of these patients had liver fibrosis based on the fibroscan examination. In the study, the only risk factor associated with the incidence of NAFLD (diagnosis based on the ultrasound examination) was body mass index (BMI) (14).

Liver biopsy remains the gold standard of NAFLD diagnosis with the severity determined histologically. However, the invasive nature of liver biopsy makes it the last resort of diagnostic means which is used in such cases that other etiologies of liver disease should be excluded in patients with NAFLD (4,8). Despite all the limitations, ultrasound is clinically easy-touse and low-cost as a diagnostic tool to detect NAFLD which usually shows no symptoms in the patients. Some parameters of ultrasonographic findings have been used to grade the severity of NAFLD to match the histological grading counterpart $(15,16)$.

Several points have become the reason to conduct this current research. To the best of our knowledge, no paper studies regarding the association between risk factors and ultrasound-based grades of NAFLD in Indonesia have been published. The management of modifiable risk factors such as obesity, glycemic control and dyslipidemia is imperative in the treatment of patients with NAFLD (8). We would like to assess if ultrasound-based grading of NAFLD severity is relevant to the existence of risk factors in type-2 diabetes patients. Therefore, the aim of this study is to understand the association between risk factors and ultrasound-based grades of NAFLD in patients with type-2 diabetes.

\section{SUBJECTS AND METHODS}

The observational study had a crosssectional design and was conducted for 6 months (May-October 2018). Research subjects who were enrolled in this study were outpatients (age 30-80 years) of the internal medicine clinic in Gotong Royong Hospital (Surabaya, Indonesia). Ninetyseven patients participated in the study but only 82 matched the criteria. The inclusion criteria were the agreement to participate voluntarily (patients filled and signed the informed consent) and the diagnosis of type- 2 diabetes had been made at least 3 months before the study was conducted. Patients would be excluded from the study if they had hepatitis B/ hepatitis C infection, non-NAFLD chronic liver diseases and anemia (hemoglobin level was lower than $12 \mathrm{~g} / \mathrm{dl}$ for males and $11 \mathrm{~g} / \mathrm{dl}$ for females, which would lower the Hemoglobin A1c level). Other exclusion criteria were regular alcohol consumption (weekly intake more than $140 \mathrm{~g}$ for males and $70 \mathrm{~g}$ for females) and long-term treatment with hepatotoxic agents (e.g. isoniazid for tuberculosis 
patients). The study protocol had gained approval from The Ethics Committee of Widya Mandala Catholic University Surabaya Faculty of Medicine.

Patients filled a data form and signed the informed consent. Information on age, gender and duration of diabetes was taken from the data form. Ages of patients were categorised into 5 groups (30-39 years, 4049 years, 50-59 years, 60-69 years and 7080 years). Patients were divided into male and female groups based on the gender option in the form. Furthermore, there were two duration of diabetes categories, patients who had diabetes for $<5$ years and $\geq 5$ years (14).

Anthropometric measurements (height and weight for BMI, waist circumference, and hip circumference) were taken afterwards. The BMI formula is weight in kilograms/ height in meters ${ }^{2}$. Patients were divided into two groups based on the BMI, ideal BMI $(<25)$ and overweight $(\geq 25)$. For the waist circumference, patients were considered to have an ideal waist circumference if the circumference $<90$ centimeters $(\mathrm{cm})$ for males and $<85 \mathrm{~cm}$ for females. Patients were considered to have a high waist circumference if the circumference $\geq 90 \mathrm{~cm}$ for males and $\geq 85$ $\mathrm{cm}$ for females. Another component of the anthropometry used for determining obesity was the waist-to-hip ratio which formula is waist circumference divided by hip circumference. The ideal waist-to-hip ratio is $<0.9$ for males and $<0.85$ for females. The high ratio is $\geq 0.9$ for males and $\geq 0.85$ for females (17).

Venous blood was taken from the patients to check the HbA1c (device: Epithod 616) and lipid profile (device: Cobas C111; total cholesterol, LDL, HDL and triglyceride) levels after fasting for 8 hours (overnight). Patients were divided into two groups based on the $\mathrm{HbA} 1 \mathrm{c}$ level, $<7 \%$ (good glycemic control) and $\geq 7 \%$ (poor glycemic control) (18). The LDL level is considered normal if the level $<100$ milligram (mg)/ deciliter (dl) and high if the level $\geq 100 \mathrm{mg} / \mathrm{dl}$. The HDL level is considered normal if the level $\geq 50 \mathrm{mg} / \mathrm{dl}$ for males and $\geq 40 \mathrm{mg} / \mathrm{dl}$ for females; and low if the level $<50 \mathrm{mg} / \mathrm{dl}$ for males and $<$ $40 \mathrm{mg} / \mathrm{dl}$ for females. The normal triglyceride level is $<150 \mathrm{mg} / \mathrm{dl}$ and the high level is $\geq 150 \mathrm{mg}$ / dl (19).

An abdominal ultrasound (device: GE, logic S7 expert) examination was performed by a competent radiologist. The ultrasound-based grades of NAFLD were as follows: (1) grade 0: normal which means there is no increase of the liver echogenicity, (2) grade 1: mild which means an increase of the liver echogenicity with normal diaphragm image and intrahepatic blood vessel lines, (3) grade 2: 
moderate which means an increase of liver echogenicity with blurred intrahepatic blood vessel lines but the diaphragm image is still normal; and (4) grade 3: severe which means an increase of liver echogenicity with blurred diaphragm image and intrahepatic blood vessel lines (20).

Data were analysed statistically using SPSS (Statistical Package for Social Sciences) version 25 . The independent variables were age, gender, duration of diabetes, BMI, waist circumference, waistto-hip ratio, $\mathrm{HbA1c}$, cholesterol, LDL, HDL, and triglyceride. The dependent variable was the ultrasound-based NAFLD grade. The comparative test used for the independent variable that consisted of two groups was the Mann-Whitney test and the Kruskal-Wallis test was for the independent variable with more than two groups. If the comparative test result was statistically significant, the Spearman's correlation test would be conducted. The p-value was significant at $\mathrm{p} \leq 0.05$.

\section{RESULTS}

Characteristics of the study subjects were presented in the table 1 below. The characteristics were the dependent (gender, age, duration of diabetes, BMI, waist circumference, waist-to-hip ratio, and laboratory test results of $\mathrm{HbA} 1 \mathrm{c}$, cholesterol, LDL, HDL and triglyceride) and independent (ultrasound-based NAFLD grade) variable parameters shown in number, percentage and mean. In this current study, 78 subjects $(95,1 \%)$ had NAFLD. Twenty-seven subjects $(32,9 \%)$ had NAFLD grade 1 based on the ultrasound examination. Grade 2 and grade 3 of NAFLD were found in $40(48,8 \%)$ and $11(13,4 \%)$ subjects, respectively.

Table 1. The characteristics of study subjects

\begin{tabular}{|c|c|}
\hline Parameter & Number, Percentage and Mean \\
\hline \begin{tabular}{c} 
Gender \\
\hdashline$-M^{2}$ \\
Female
\end{tabular} & $\begin{array}{l}31(37,8 \%) \\
51(62,2 \%)\end{array}$ \\
\hline $\begin{array}{c}\text { Age (years) } \\
: \quad 30-39 \\
: \quad 40-49 \\
: \quad 60-59 \\
=\quad 70-80\end{array}$ & $\begin{array}{c}4(4,99 \%) \\
12(14,6 \%) \\
27(32,9 \%) \\
33(40,3 \%) \\
6(7,3 \%) \\
\end{array}$ \\
\hline \begin{tabular}{c} 
Duration of diabetes (years) \\
$: \quad<=5$ \\
\hdashline$=5$
\end{tabular} & $\begin{array}{l}41(50 \%) \\
41(50 \%)\end{array}$ \\
\hline \begin{tabular}{c} 
Body mass index \\
$: \quad<25$ (ideal) \\
\hdashline$=25$ (high)
\end{tabular} & $\begin{array}{l}41(50 \% \%) 22,07+2,24 \\
41(50 \% \%) 29,48+4.25\end{array}$ \\
\hline 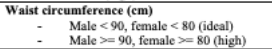 & $\begin{array}{l}20(24,4 \% \% 77,81 \pm 9,05 \\
62(7,6 \%) 96,46+13,85\end{array}$ \\
\hline 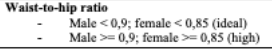 & 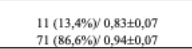 \\
\hline $\begin{array}{c}\text { HbAIC level (\%) } \\
\quad<7 \text { (godd glycemic control) } \\
:=>7 \text { (poor glycemic control) }\end{array}$ & $\begin{array}{l}17(20,7 \%) 6,51 \pm 0,35 \\
65(79,3 \% \times 9,34 \pm 1.95\end{array}$ \\
\hline $\begin{array}{c}\text { Cholesterol(mig/dl) } \\
: \quad>200 \text { (nomal) } \\
\quad>200 \text { (high) }\end{array}$ & $\begin{array}{l}51(62,2 \%) / 167,37+23,48 \\
31(37,8 \% / 233,90+23,27\end{array}$ \\
\hline $\begin{array}{c}\text { LDL (mg/dl) } \\
\quad=\quad<00 \text { (normal) } \\
\quad>=100 \text { (high) }\end{array}$ & $\begin{array}{r}18(22 \%) 86,28+12,77 \\
64(78 \%) \times 148,53 \pm 30,15\end{array}$ \\
\hline $\begin{array}{c}\text { HDL (my/dil) } \\
\because \quad \text { Male }>50 \text {, female }>40 \text { (normal) } \\
\text { Male }<50 \text {, female }<40 \text { (low) }\end{array}$ & $\begin{array}{l}52(63,4 \% / 5 / 54,98 \pm 8,13 \\
30(36,6 \%) / 39,20 \pm 5,89\end{array}$ \\
\hline $\begin{array}{c}\text { Triglyceride (mg/dil) } \\
: \quad<150 \text { (normal) } \\
x=150 \text { (high) }\end{array}$ & $\begin{array}{l}48(58,5 \%) 104,98 \pm 27,24 \\
34(41,5 \%)(214,85 \pm 74,20\end{array}$ \\
\hline 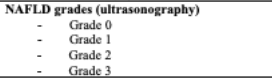 & $\begin{array}{l}4(4,9 \%) \\
27(32,9 \%) \\
40(48,8 \%) \\
11(13,4 \%) \\
\end{array}$ \\
\hline
\end{tabular}

Non-modifiable risk factors (table 2) in the current research were gender, age, and duration of diabetes. There was no significant difference in ultrasound-based NAFLD grades between two gender groups in the study $(p=0.954)$. The significant difference was found across age groups $(\mathrm{p}=$ 0.028), but the correlation test result was not significant $(\mathrm{p}=0.691)$. The comparative test result showed no difference between the two groups of diabetes duration $(\mathrm{p}=0.525)$.

Table 2. Ultrasound-based NAFLD grades across non-modifiable risk factor groups 


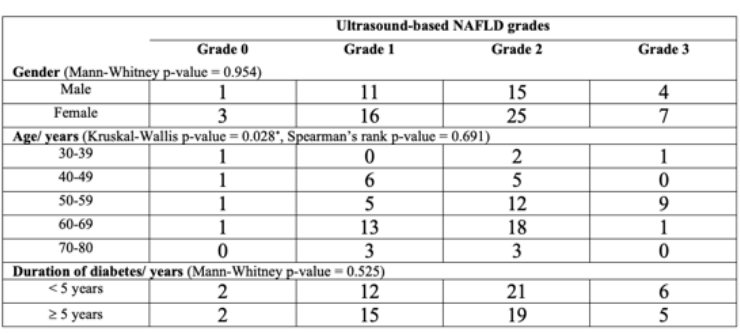

*p-value $\leq 0.05$

The anthropometric parameters (table 3) used to study the obesity risk factors were BMI, waist circumference and waist-to-hip ratio. The significant difference of comparative test was found between two BMI groups $(\mathrm{p}=0.000)$ and the correlation test result was also significant $(\mathrm{p}=0.000, \mathrm{r}$ $=0.390)$. The $p$-value of comparative test between two waist circumference groups was 0.063 (no significant difference). There was no significant difference either between two waist-to-hip ratio groups $(\mathrm{p}=0.371)$.

Table 3. Ultrasound-based NAFLD grades across anthropometric parameters (obesity risk factors)

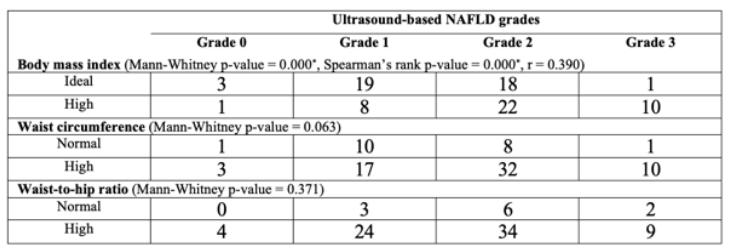

*p-value $\leq 0.05$

Laboratory test parameters (table 4) were checked in the patients to analyse diabetes (glycemic control) and dyslipidemia risk factors. The significant difference was not found between two glycemic control groups $(p=0.437)$. For the dyslipidemia risk factors, the significant difference was not found between two groups of LDL $(p=0.966)$, HDL $(p=$ $0.575)$ and triglyceride $(\mathrm{p}=0.060)$ levels. The ultrasound-based NAFLD grades were significantly different across two total cholesterol (normal and high) groups ( $\mathrm{p}=$ 0.033). The total cholesterol was positively correlated with the NAFLD grades $(\mathrm{p}=$ $0.033, \mathrm{r}=0.237)$.

Table 4. Ultrasound-based NAFLD grades across laboratory parameter groups

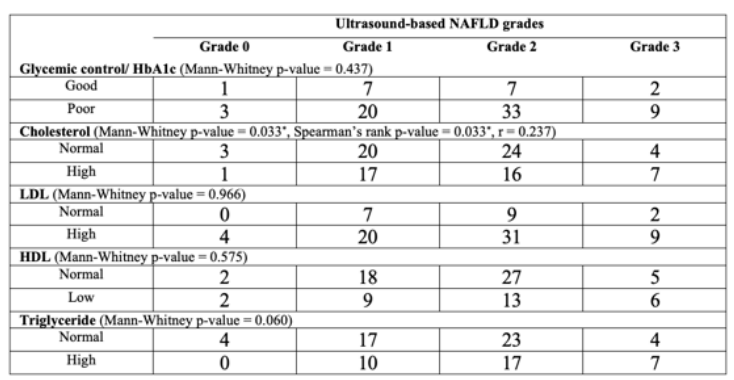

${ }^{*}$-value $\leq 0.05$

\section{DISCUSSION}

In the present study $95,1 \%$ of the type2 diabetes patients had NAFLD. Other hospital-based studies have shown the similar high prevalence of NAFLD in type2 diabetes patients. Based on a Chinese systematic review of 24 studies 54.31$64.92 \%$ of type- 2 diabetes patients have been diagnosed with NAFLD (21). Liver biopsy-proven NAFLD diagnosis has even been made in $87 \%$ of the type- 2 patients in the Indian hospital (22). Data from the study in the hospital in Jakarta, Indonesia has given information that $45.2 \%$ of type- 2 diabetes patients had NAFLD (14). This means that the present study prevalence has 
surpassed the one from the previous study in Indonesia by a high percentage.

The current study showed that there was no association between gender and ultrasound-based NAFLD grade. This contradicts the theory which explains that free fatty acid (FFA) degradation rate is lower in men than women. As a result, more FFA accumulates in the liver of men (23). Previous studies have supported the theory. More men have NAFLD than women in a meta-analysis study based on epidemiologic research (13). Interesting results of gender as the risk factor come from a systematic review about NAFLD in Asia. The study has shown that before age 50 , the number of men having NAFLD is twice as high as the women's number but when they are older, more women will have NAFLD (24).

There was a significant difference in the NAFLD grades based on the ultrasound examination across age groups but no significant correlation was found in the study. A molecular biology theory supports the relationship between ageing and NAFLD. An experiment in mice which was comparable to ageing humans has shown that the lack of nicotinamide adenine dinucleotide $\left(\mathrm{NAD}^{+}\right)$is associated with NAFLD. This is because $\mathrm{NAD}^{+}$is an important nucleotide as a co-factor in the mitochondrial activity in the liver. Thus, the deficiency of this element results in the accumulation of liver FFA. The geneticallyengineered mouse model and ageing human with NAFLD in the experimental study had the deficiency (25). Moreover, ageing is an independent risk factor of NAFLD-related liver fibrosis (26).

Obesity is a major risk factor for both type 2 diabetes and NAFLD. Urbanisation in Asia which has changed the society from the agricultural one to the industrial one is increasing the obesity prevalence because of the rife unhealthy lifestyle. The high BMI $(\geq 25)$ as an anthropometric measurement for obesity diagnosis in relation with NAFLD may be misleading as some Asian people (8-19\%) with BMI <25 known as having 'lean' NAFLD $(2,27)$. In the present study the higher BMI is associated with the increase of ultrasound-based NAFLD grades (the p-value of Spearman's rank test was significant, 0.000 and $r=0.390$ ).

The aforementioned 'lean' characteristic of NAFLD in Asian population suggests that other anthropometric measurements such as waist circumference and waist-to-hip ratio to detect abdominal obesity as a more accurate indicator of NAFLD $(2,12)$. However, none of the two anthropometric measurement sets of groups (ideal and high) were associated with ultrasound-based grades of NAFLD. As an explanation to these results, the cut-off points of the two measurements as the indicator to foresee that someone has 
the potential to develop NAFLD may differ from one population to another (17).

Given the notion that NAFLD is the hepatic feature of metabolic syndrome, this explains why type 2 diabetes is strongly associated with the metabolic liver disease. Moreover, insulin resistance as the cause of type 2 diabetes is one of the major factors in the pathogenesis of NAFLD (28). Another reason why diabetes is associated with some liver diseases is that the liver plays an important role to regulate glucose metabolism. In a case-control study conducted in an American hospital, patients with higher durations of diabetes had higher risks of developing hepatocellular carcinoma (29). A hospital-based study in Nigeria has shown that there was no significant difference of diabetes duration in different ultrasound-based NAFLD grades of type-2 diabetes patients (20). No significant difference has been found in the presence of NAFLD between patients who had type- 2 diabetes $\geq 5$ years and the counterpart in a study in Jakarta (14). The NAFLD grades based on ultrasonography were not different significantly in the two diabetes duration groups in our study.

Glycemic control is imperative in efforts to prevent complications in type-2 diabetes patients. The A1c type of hemoglobin can be used to evaluate if someone has a long exposure of hyperglycemia (18). However, there was no significant difference in ultrasound-based NAFLD grades between patients with good and poor glycemic control. There has not been a significant difference either in glycemic control between different NAFLD grades of the Nigerian type-2 diabetes patients (20). The glycemic control index which is a result of glycated albumin divided by HbAlc may be a better biomarker to predict the progression of NAFLD based on the ultrasound examination as the study in Korea has shown (30).

The only component of the lipid profile associated with ultrasound-based NAFLD grades in this study was total cholesterol. Total cholesterol in the two groups (high and normal total cholesterol) was positively correlated with the grades. Regardless of the ethnicity background and locations, dyslipidemia is a major risk factor of NAFLD. Dyslipidemia prevalence along with obesity is increasing in Asia and strongly associated with the prevalence increase of NAFLD (31,32). A study proved that there is a significant link between dyslipidemia (the increase of total cholesterol, LDL, triglyceride, and the decrease of HDL) and the increase grades of NAFLD based on the ultrasound examination (19).

Several limitations might have occurred in this study. The sample number might not be enough to represent the total 
number of type- 2 diabetes patients who visit the hospital. The risk factor categories that had a big discrepancy of the patient number in the grouping appeared to have an insignificant statistical result. Another limitation might come from the diagnostic tool. The ultrasound device may not detect hepatic steatosis when it is lower than $20 \%$. Its grading system can hardly be correlated with the histological severity categories. Fibrosis in NASH cannot be detected. The subcutaneous fat might also cause false echogenicity $(15,16)$. As a solution, the scoring system that combines ultrasoundbased grades with metabolic features might help (33).

\section{CONCLUSION}

The risk factors associated with NAFLD grades based on ultrasonography are age, BMI and total cholesterol. The higher BMI and total cholesterol are correlated with the increase of the NAFLD grades. These results suggest that the importance of lifestyle modification (healthy diet and exercise) to prevent NAFLD progression should be promoted among type- 2 diabetes patients.

\section{REFERENCE}

1. Younossi ZM, Koenig AB, Abdelatif D, Fazel Y, Henry L, Wymer M. Global epidemiology of nonalcoholic fatty liver diseaseMeta-analytic assessment of prevalence, incidence, and outcomes. Hepatology. 2016;64(1):73-84.

2. Fan JG, Kim SU, Wong VWS. New trends on obesity and NAFLD in Asia. J Hepatol. 2017;67(4):862-73.

3. Bhala N, George J. The burden of Non-Alcoholic Fatty Liver Disease (NAFLD) in the Asia Pacific region. Curr Hepat Rep. 2015;14(2):77-86.

4. Abd El-Kader SM, El-Den Ashmawy EMS. Non-alcoholic fatty liver disease: The diagnosis and management. World J Hepatol. 2015;7(6):846-58.

5. Brunt EM. Pathology of nonalcoholic fatty liver disease. Nat Rev Gastroenterol Hepatol. 2010;7(4):195-203.

6. Jiang CM, Pu CW, Hou YH, Chen Z, Alanazy M, Hebbard L. Non alcoholic steatohepatitis a precursor for hepatocellular carcinoma development. World J Gastroenterol. 2014;20(44):16464-73.

7. Wong RJ, Cheung R, Ahmed A. Nonalcoholic steatohepatitis is the most rapidly growing indication for liver transplantation in patients with hepatocellular carcinoma in the U.S. Hepatology. 2014;59(6):2188-95.

8. Chalasani N, Younossi Z, Lavine JE, Diehl AM, Brunt EM, Cusi K, et al. The diagnosis and management of 
non-alcoholic fatty liver disease:

Practice Guideline by the American Association for the Study of Liver Diseases, American College of Gastroenterology, and the American Gastroenterological Association. Hepatology. 2012;55(6):2005-23.

9. Manco M. Insulin Resistance and NAFLD: A Dangerous Liaison beyond the Genetics. Children. 2017;4(8):74.

10. Loomba R, Abraham M, Unalp A, Wilson L, Lavine J, Doo E, et al. Association between diabetes, family history of diabetes, and risk of nonalcoholic steatohepatitis and fibrosis. Hepatology. 2012;56(3):943-51.

11. Bian Z, Millwood IY, Hao J, Han X, Zang Y, Chen J, et al. Diabetes, Plasma Glucose, and Incidence of Fatty Liver, Cirrhosis, and Liver Cancer: A Prospective Study of 0.5 Million People. Hepatology. 2018;68(4):1308-18.

12. Zheng Y, Ley SH, Hu FB. Global aetiology and epidemiology of type 2 diabetes mellitus and its complications. Nat Publ Gr. 2017;14(2):88-98.

13. Vernon G, Baranova A, Younossi ZM. Alimentary Pharmacology and Therapeutics Systematic review : the epidemiology and natural history of non-alcoholic fatty liver disease and non-alcoholic steatohepatitis in adults. Aliment Pharmacol Ther. 2011;34:274-85.

14. Prasetya IB, Hasan I, Wisnu W, Rumende CM. Prevalence and Profile of Fibrosis in Diabetic Patients with Non-alcoholic Fatty Liver Disease and the Associated Factors. Acta Med Indones. 2017;49(2):91-8.

15. Khov N, Sharma A, Riley TR. Bedside ultrasound in the diagnosis of nonalcoholic fatty liver disease. World J Gastroenterol. 2014;20(22):6821-5.

16. Ruben Hernaez, Mariana Lazo, Susanne Bonekamp, Ihab Kamel, Frederick L. Brancati, Eliseo Guallar JMC. Diagnostic Accuracy and Reliability of Ultrasonography for the Detection of Fatty Liver: A MetaAnalysis.

Hepatology. 2011;54(3):1082-90.

17. Singh A, Parida S, Narayan J, Nath P, Padhi PK, Pati GK, et al. Simple Anthropometric Indices are Useful for Predicting Non-alcoholic Fatty Liver Disease [NAFLD] in Asian Indians. J Clin Exp Hepatol [Internet]. 2017; $\quad$ xx(xx):1-6. Available from: http://dx.doi.org/10.1016/j.jceh.201 7.05.005 
18. American Diabetes Association.

Diagnosis and classification of diabetes mellitus. Diabetes Care. 2010;33(SUPPL. 1).

19. Mahaling DU, Basavaraj MM, Bika AJ. Comparison of lipid profile in different grades of non-alcoholic fatty liver disease diagnosed on ultrasound. Asian Pac J Trop Biomed. 2013;3(11):907-12.

20. Afolabi BI, Ibitoye BO, Ikem RT, Omisore AD, Idowu BM, Soyoye DO. The Relationship Between Glycaemic Control and NonAlcoholic Fatty Liver Disease in Nigerian Type 2 Diabetic Patients. J Natl Med Assoc. 2017;10(6):1-9.

21. Dai W, Ye L, Liu A, Wen SW, Deng $\mathrm{J}$, Wu X, et al. Prevalence of nonalcoholic fatty liver disease in patients with type 2 diabetes mellitus. Medicine (Baltimore). 2017;96(39).

22. M Prashanth, HK Ganesh, MV Vimal, M John, $\mathrm{T}$ Bandgar, Shashank R Joshi, SR Shah, PM Rathi, AS Joshi, Hemangini Thakkar, PS Meno NS. Prevalence of Nonalcoholic Fatty Liver Disease in Patients with Type 2 Diabetes Mellitus. JAPI. 2009;57(May 2014):205-10.

23. Pramfalk C, Pavlides M, Banerjee R, Mcneil CA, Neubauer S, Karpe F, et al. Sex-Specific Differences in Hepatic Fat Oxidation and Synthesis May Explain the Higher Propensity for NAFLD in Men. $J$ Clin Endocrinol Metab. 2015;100(December):4425-33.

24. Farrell GC, Wong VW, Chitturi S. Reviews NAFLD in Asia - as common and important as in the West. Nat Publ Gr. 2013;10(5):30718.

25. Miao CC, Wang P, Military S, Zhou C, Yang X, Hua X, et al. Hepatic NAD+ deficiency as a therapeutic target for non-alcoholic fatty liver disease in ageing. $\mathrm{Br} \mathrm{J}$ Pharmacol. 2016;172:2352-2368.

26. Frith J, David J, Newton JL. Chronic liver disease in an ageing population. Age Ageing. 2009;38(1):11-8.

27. Yoon KH, Lee JH, Kim JW, Cho JH, Choi YH, Ko SH, et al. Epidemic obesity and type 2 diabetes in Asia. Lancet. 2006;368(9548):1681-8.

28. Firneisz G. Non-alcoholic fatty liver disease and type 2 diabetes mellitus: The liver disease of our age? World $\mathbf{J}$ Gastroenterol. 2014;20(27):907289.

29. Javle M, Dalia MM, Lozano RD, Abbruzzese JL. Association of diabetes duration and diabetes treatment with the risk of hepatocellular carcinoma. Cancer. 
2010;116(8):1938-46.

30. Jung C, Lee B, Choi D, Jung S, Kim

B, Kim C, et al. Association of grade

of non-alcoholic fatty liver disease and glycated albumin to glycated hemoglobin ratio in patients with type 2 diabetes mellitus. Diabetes Res Clin Pr. 2017;125:53-61.

31. Amarapurkar DN, Hashimoto E, Lesmana LA, Sollano JD, Chen PJ, Goh KL. How common is nonalcoholic fatty liver disease in the Asia-Pacific region and are there local differences? J Gastroenterol Hepatol. 2007;22(6):788-93.

32. Agrawal S, Duseja AK. Nonalcoholic Fatty Liver Disease: East Versus West. J Clin Exp Hepatol. 2012;2(2):122-34.

33. Mishra P, Younossi ZM. Abdominal Ultrasound for Diagnosis of Nonalcoholic Fatty Liver Disease (NAFLD). Am J Gastroenterol. 2007

Dec 1;102:2716. 